\title{
Elderly Perceptions of Social Capital and Age-Related Disaster Vulnerability
}

\author{
Michelle Annette Meyer, PhD
}

\section{ABSTRACT}

Objective: Elderly individuals are considered at elevated risk of disaster impacts owing to increased health concerns, reduced mobility, and fixed economic resources. Social capital can counteract these vulnerabilities by increasing the likelihood of hearing disaster warnings, providing social ties to assist with preparation and evacuation, and providing access to financial or nonfinancial resources. I aimed to analyze the relationship between age and perceptions of disaster-related social capital.

Methods: I used mailed surveys and in-person interviews with a sample of residents from 2 Florida counties to study perceptions of social capital available for disaster.

Results: The results showed that age has a negative effect on perceptions of social capital resources available during a disaster. The elderly reported fewer social ties overall and much fewer social ties that could provide financial assistance, if necessary, during a disaster.

Conclusions: These results indicate that social capital may not counteract the social vulnerabilities of elderly persons to disaster impacts. (Disaster Med Public Health Preparedness. 2017;11:48-55)

Key Words: hurricane, social networking, social capital, elderly, disasters

$\mathrm{D}$ eclining health and economic constraints can place the elderly at increased risk of injury, death, and physical and psychological loss during disasters. ${ }^{1,2}$ But aspects of the social environment, including elderly persons' social capital from informal network ties, can counteract or compound these physiological vulnerabilities. Unfortunately, less is known about the effects of social capital on disaster risk and recovery for this population. Drawing on survey and interview data with residents of Florida, I expand on social capital's effect on age-related vulnerability to disaster. My analyses highlight differences in disaster-specific social capital available for elderly and nonelderly persons.

\section{Elderly Vulnerability to Disaster}

Social vulnerability to disaster is described as "the characteristics of a person or group and their situation that influence their capacity to anticipate, cope with, resist and recover from the impact of a natural hazard." $3(\mathrm{p} 11)$ When disaster strikes, older individuals are among the most vulnerable and are more likely to be injured and to perish. ${ }^{4,5}$ This difference is less a function of age but more related to changes associated with aging, including declining economic resources and physical and mental health functioning, and, potentially, less social network support. ${ }^{6}$

Economic resources are necessary to prepare for and respond to a disaster (for review, see Fotherfill and
Peek ${ }^{7}$ ). Elderly persons with higher socioeconomic status are more likely to report adequate insurance coverage and greater access to federal aid in a disaster. ${ }^{1}$ Overall, elderly poverty rates have declined and are currently below the poverty rates for nonelderly persons. ${ }^{8}$

While poverty rates are lower for the elderly than for other age groups, the elderly are more likely to live on fixed incomes, which affects their ability to gather and access resources in an emergency. ${ }^{9}$ For example, Bolin and Klenow found that the elderly had more difficulty getting post-disaster loans and more difficulty making up a discrepancy between financial losses and what was covered by insurance than did their younger counterparts. ${ }^{5}$ Thus, nearly twice as many elderly respondents as nonelderly respondents reported a drop in their standard of living after a disaster.

Declining health is the most common explanation of elderly disaster vulnerability. Because advancing age is correlated with the likelihood of having chronic health conditions or special needs, elderly individuals may have limited ability to respond to disaster warnings and take protective action (eg, tucking under tables during an earthquake). ${ }^{4,9}$ Individuals with a physical disability or health condition may have greater difficulty preparing supplies for evacuation, evacuating without assistance, or completing cleanup following an event. ${ }^{10}$ These economic and health vulnerabilities may be counteracted by the elderly's social capital. ${ }^{11}$ 


\section{Elderly and Disaster-Specific Social Capital}

Social capital describes the resources available through social networks. ${ }^{12}$ Social capital is important during all phases of disaster. For example, warnings and information flow through social networks, and friends and family assist with preparedness activities. ${ }^{13}$ During the immediate response period, friends, family, and neighbors check on the well-being of others, provide life-saving assistance, ${ }^{14(\mathrm{p} 357), 15}$ and those outside the affected area provide temporary shelter. ${ }^{16}$ During recovery, social networks are conduits for resources including childcare, ${ }^{17}$ emotional support, ${ }^{18}$ and rebuilding and repair assistance, among many others. ${ }^{5,16,19,20}$

Disaster research shows how network size affects the outcomes for disaster victims. Network size describes the number of persons with whom an individual has a specific type of relationship. $^{21,22}$ Individuals with small networks have higher rates of psychological and physical trauma, have longer recovery rates, and are more likely to perish in a disaster than those with larger networks. ${ }^{23}$ Individuals with larger social networks generally receive more tangible (eg, debris removal), informational (eg, directions to formal aid resources), and emotional (eg, encouragement) assistance in disasters. ${ }^{18}$ On average in the United States, individuals report that about 3 to 5 persons assisted them before, during, or following a disaster. ${ }^{24}$

Yet, social network sizes, in general, decline with age in the United States, even as reduced physical and cognitive abilities leave elderly populations more dependent on others for assistance. ${ }^{25}$ The term pattern of neglect has been used to describe findings that indicate elderly individuals were less likely to draw upon family, neighbors, or friends for aid during or after a disaster and were less likely to receive formal assistance from government and community organizations whether that assistance be tangible or emotional. ${ }^{5,26}$ Klinenberg identified the importance of social ties to surviving the Chicago heat wave of 1995, wherein deaths in the disaster were concentrated among isolated, elderly populations. ${ }^{27}$

\section{METHODS}

In this article, I connected elderly vulnerability and social capital to focus on pre-event perceptions of disaster-specific social capital. Perceived support has been shown to affect individuals' capacity to cope with traumatic situations even beyond the actual support received from their network. ${ }^{28,29}$ Thus, individual perceptions of networks are important, although limited in that it is unknown whether these perceptions become actualized in a disaster. Using quantitative and qualitative measures, I described how perceptions of social capital availability for disaster resources differ between elderly and nonelderly persons.

I followed the tradition of Bourdieu ${ }^{12}$ and $\operatorname{Lin}^{30}$ and defined social capital as a social network-based asset, specifically, as the resources available through a social network that can be activated to meet one's needs. In this case, the needs are related to disaster. This conceptualization focuses on social capital for individual resilience rather than community resilience, and, as argued in the social capital literature, ${ }^{31}$ is conceptually distinct from that of social capital based on community groups or civic participation. ${ }^{32-34}$ Based on the literature, I hypothesized that elderly persons would report less social capital than nonelderly persons.

Data were from mailed surveys and in-person interviews conducted in 2012 in 2 Florida counties: Leon and Dixie. Leon and Dixie counties have less migration than other areas of Florida, resulting in more people who have lived many years with coastal hazards. As noted in Table 1, the median number of years living along the coast for respondents was nearly 30 and the median number of coastal storms experienced was 3 . Thus, while these individuals provided preevent perceptions, most were disaster-experienced.

Because the 2 counties differed in population density, I used different random sampling strategies for the mailed survey. In Dixie County, the low population density allowed for a random sample of 300 addresses from the county. In Leon County, which had a higher population density, I performed stratified cluster sampling to increase participation of vulnerable populations and gather a more representative sample. I selected 6 Census tracts and then 50 households within each tract based on demographic factors related to social vulnerability. ${ }^{\text {a }}$ Survey Sampling International drew the samples.

I used 4 mailings: a prenotification postcard, the survey, a reminder postcard, and a second survey with a $\$ 1$ incentive. ${ }^{35}$ After removing undeliverable addresses, 529 addresses remained (275 from Dixie County and 254 from Leon County). Twenty-two households declined to participate. The response rate was $27 \%$ with 138 responses. The response rate was low, but comparable to mail survey research. ${ }^{36,37}$ Respondents were representative of the population of each county, except that respondents were older and more likely to have a disability (Table 1 ). The elderly respondents were $45 \%$ women and ranged in age from 65 to 93 years with about $55 \%$ of elderly respondents between 65 and 74 years of age. The elderly respondents' income and employment status were similar to the US elderly population. Eight percent of elderly respondents were below the poverty line, and median household income fell between $\$ 30,000$ and $\$ 45,000$,

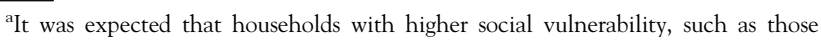
living in poverty or racial minorities, would respond at a lower rate than others. Because I could not determine which addresses contained more or less socially vulnerable individuals, I oversampled at the mailing stage from Census tracts with a high population of socially vulnerable individuals to compensate for this concern. I used 8 variables common in economic and demographic analysis of disaster resilience and social vulnerability to identify Census tracts with potentially more or less vulnerable populations: percent poverty, median income, percent racial minority, household size, percent female-headed households, percent renters, percent elderly, and percent children. I purposefully selected 2 tracts with the highest vulnerability on these factors, 2 tracts with the lowest, and 2 tracts in the middle. 


\section{TABLE 1}

\section{Survey and Interview Participant Demographics}

\begin{tabular}{|c|c|c|c|c|c|c|c|c|}
\hline & \multicolumn{3}{|c|}{ Surveys } & \multicolumn{3}{|c|}{ Interviews } & \multicolumn{2}{|c|}{2010 Census } \\
\hline & $\begin{array}{c}\text { Dixie } \\
(n=75)\end{array}$ & $\begin{array}{c}\text { Leon } \\
(n=63)\end{array}$ & $\begin{array}{c}\text { Total } \\
(n=138)\end{array}$ & $\begin{array}{c}\text { Dixie } \\
(n=9)\end{array}$ & $\begin{array}{c}\text { Leon } \\
(n=16)\end{array}$ & $\begin{array}{c}\text { All } \\
(n=25)\end{array}$ & Dixie & Leon \\
\hline Median age, y & 62 & 57 & 60 & 62 & 59 & 60 & 45 & 30 \\
\hline Persons 65 y or older, \% & 42.50 & 25.80 & 34.80 & 45.45 & 14.29 & 28.00 & 19.3 & 9.4 \\
\hline Disability, \% & & & & & & & 33.5 & 8.9 \\
\hline Respondent has a disability & 28.40 & 9.70 & 19.90 & 72.73 & 7.14 & 36.00 & & \\
\hline Member of household has a disability & 24.60 & 6.20 & 16.20 & 60.00 & 0.00 & 22.73 & & \\
\hline \multicolumn{9}{|l|}{ Race, \% } \\
\hline White & 91.70 & 67.20 & 80.50 & 90.91 & 64.29 & 76.00 & 90.9 & 63.0 \\
\hline Black/African American & 1.40 & 31.10 & 15.00 & 0.00 & 35.71 & 20.00 & 0.0 & 30.3 \\
\hline Asian & 0.00 & 0.00 & 0.00 & 0.00 & 0.00 & 0.00 & 0.0 & 2.9 \\
\hline Other or two or more races & 7.00 & 1.60 & 4.60 & 9.09 & 0.00 & 4.00 & 9.1 & 3.8 \\
\hline Female, \% & 51.40 & 54.10 & 52.60 & 54.55 & 57.14 & 52.00 & 46.2 & 52.4 \\
\hline Annual household income, \% & & & & & & & $\begin{array}{l}\text { Median } \\
\$ 32,312\end{array}$ & $\begin{array}{l}\text { Median } \\
\$ 44,490\end{array}$ \\
\hline$<\$ 15,000$ & 23.08 & 21.43 & 21.77 & 44.44 & 23.08 & 31.82 & & \\
\hline$\$ 15,000-\$ 30,000$ & 24.62 & 14.29 & 20.16 & 22.22 & 15.38 & 18.18 & & \\
\hline$\$ 30,000-\$ 45,000$ & 21.54 & 12.50 & 19.35 & 11.11 & 15.38 & 13.64 & & \\
\hline$\$ 45,000-\$ 60,000$ & 9.23 & 10.71 & 9.68 & 0.00 & 0.00 & 0.00 & & \\
\hline$\$ 60,000-\$ 75,000$ & 7.69 & 10.71 & 8.87 & 11.11 & 7.69 & 9.09 & & \\
\hline$\$ 75,000-\$ 130,000$ & 9.32 & 25.00 & 16.13 & 11.11 & 30.77 & 22.73 & & \\
\hline$>\$ 130,000$ & 3.08 & 1.79 & 4.03 & 0.00 & 7.69 & 4.55 & & \\
\hline \multicolumn{9}{|l|}{ Educational attainment, \% } \\
\hline High school degree or higher & 90.40 & 93.70 & 91.90 & 91.91 & 76.92 & 83.33 & 72.6 & 90.6 \\
\hline Bachelor's degree or higher & 24.60 & 57.10 & 39.70 & 27.27 & 53.85 & 41.66 & 6.2 & 41.3 \\
\hline \multicolumn{9}{|l|}{ Employment, \% } \\
\hline Full-time & 34.29 & 59.32 & 45.74 & 27.27 & 42.86 & 36.00 & $43.0^{\mathrm{a}}$ & $66.9^{a}$ \\
\hline Part-time & 5.71 & 3.39 & 4.65 & 18.18 & 21.43 & 20.00 & & \\
\hline Retired & 41.43 & 23.73 & 33.33 & 36.36 & 28.57 & 32.00 & & \\
\hline Not employed & 8.57 & 10.17 & 9.30 & 18.18 & 7.14 & 12.00 & $10.2^{\mathrm{b}}$ & $8.4^{b}$ \\
\hline Homeowners, \% & 90.70 & 58.10 & 75.90 & 90.91 & 57.14 & 72.00 & 81.6 & 53.8 \\
\hline Mean household size, No. & 2.39 & 2.06 & 2.24 & 2 & 2 & 2 & 2.4 & 2.4 \\
\hline Relationship, \% & & & & & & & - & - \\
\hline Married & 52.80 & 40.30 & 47.00 & 45.45 & 57.14 & 52.00 & & \\
\hline Cohabitating & 11.10 & 8.10 & 9.70 & 27.27 & 7.14 & 16.00 & & \\
\hline Divorced/widowed & 31.90 & 27.40 & 29.90 & 27.27 & 28.57 & 28.00 & & \\
\hline Single & 4.20 & 24.20 & 13.40 & 0.00 & 7.14 & 4.00 & & \\
\hline Median years living on coast, y & 34 & 29 & 31 & 35 & 40 & 35 & - & - \\
\hline Median years living in county, y & 19 & 32 & 24 & 22 & 35 & 28 & - & - \\
\hline Median number of hurricanes, No. & 3 & 2 & 3 & 1 & 3 & 2 & - & - \\
\hline
\end{tabular}

${ }^{a}$ American Community Survey 2010, percentage of persons 16 years and older in the labor force.

${ }^{\mathrm{b}}$ American Community Survey 2010, percentage of persons 16 years and older unemployed.

compared to national median elderly family incomes of $\$ 48,000$ and $9 \%$ elderly poverty in 2011 . Also, about $15 \%$ of the elderly respondents were in the labor force compared to $18 \%$ of the US elderly population. The elderly respondents in this study were more highly educated on average than other elderly with $95 \%$ having at least a high school diploma compared to $81 \%$ nationally.

I measured social capital by using a social network name generator. $^{38(\mathrm{p} 21)}$ Respondents listed up to 8 people who they "would turn to for assistance after a hurricane." Respondents provided the following for each person: relationship, age, and type of disaster assistance that this person could provide (financial or nonfinancial). Financial assistance was defined as monetary assistance, such as helping with evacuation or rebuilding costs, whereas nonfinancial assistance was described as other forms of assistance such as offering labor, childcare, or emotional support. Network size was the total number of social ties each respondent listed in the name generator, which was then specified by resource type (financial or nonfinancial).

The final question on the survey asked for an in-person interview and offered a $\$ 10$ incentive. I conducted semistructured interviews with 25 individuals, 9 from Dixie County and 16 from Leon County. Gathering social network 
data through these open-ended questions allowed me to understand how individuals described certain relationships as important in disaster contexts and what particular traits interviewees used to determine selection for these networks. ${ }^{19,39}$ The interviews ranged in length from 20 minutes to 2 hours, were digitally recorded, and were transcribed verbatim. I coded and recoded the interview data in 3 stages. ${ }^{40}$ I performed open coding of basic themes in the data, then examined relationships between these themes and finally identified core concepts and performed selective coding based on these concepts. ${ }^{41,42}$ All names were changed to protect confidentiality.

\section{RESULTS}

The findings depicted individuals' perceptions of their social capital available in disasters. The respondents' disaster-related social networks ranged in size from 0 to 8 (the maximum range of the name generator), with an average of 3 to 4 persons (Table 2). This finding corresponded with previous research on the size of support networks following a disaster. ${ }^{24}$ Elderly and nonelderly survey respondents differed significantly in the overall number of persons listed, with elderly respondents identifying 3.0 persons compared to 4.1 persons listed by nonelderly respondents. This result supported the hypothesis that the elderly would report less social capital.

The interviews provided examples of elderly persons with various network sizes. Rick, a married, elderly man who had custody of his 3-year-old grandson, had an average-sized network for his age group. His network included 2 other elderly persons (his mother and a neighbor) and a neighbor's nephew:

Maybe my mother. She's about the only one [I would turn to for disaster assistance].... Well, probably the neighbor [too]. We had a power outage last week, and I know the one lady next door, the generator never kicked on. I had to have her nephew teach me how to run that thing so I could take care of it. That's about the only people I could think of.

Adelle, a 90-year-old resident of Dixie County who lived alone, was an example of a person with a large social network. Adelle listed 8 people on the survey and in the interview included her 4 children and their spouses, a weekly housekeeper, 2 neighbors, and several fellow church members. But Adelle also recounted a story of a recent accident in her home when she fell from bed and was too injured to reach the phone. She described lying on the floor for several hours before the housekeeper arrived and called 911. She expressed her luckiness that it had been housecleaning day; otherwise, she would have had to wait until one of her sons came to visit. Although Adelle had a large network, her discussion demonstrates the importance of social capital to counteract the physical vulnerability related to aging.

As noted in the above examples, family was central to disasterrelated support. But the availability of family may vary by age. For example, Nina, an elderly woman from Dixie County who lived with her special needs adult daughter, explained that since her parents were deceased, she had to evacuate to her brother's house during a recent storm, "My mother and father had passed away. It's just my daughter and I, and my brother lived down the street." This brother passed away after that storm and no other family lived in the area to assist her and her daughter. In contrast, Mitchell, a 30-year-old married father of 2 in Dixie County, had several family members who could assist him, including his mother, mother-in-law, father, and brother, "I've also got a brother than lives down in Leesburg. If worse comes to worse and something really bad happens and my dad can't help me, I'll call him up."

These quotes described nonfinancial assistance, such as help starting a generator or assistance getting medical care. Often

\begin{tabular}{|c|c|c|c|c|c|c|}
\hline \multicolumn{7}{|c|}{ Perceived Social Capital Resources Available in a Disaster ${ }^{a}$} \\
\hline \multirow[b]{2}{*}{$\begin{array}{l}\text { Number of } \\
\text { Ties }\end{array}$} & \multicolumn{2}{|c|}{ Financial, \% } & \multicolumn{2}{|c|}{ Nonfinancial, \% } & \multicolumn{2}{|c|}{ Overall, \% } \\
\hline & $\begin{array}{c}\text { Elderly } \\
(n=46)\end{array}$ & $\begin{array}{l}\text { Nonelderly } \\
(\mathrm{n}=\mathbf{8 8})\end{array}$ & $\begin{array}{l}\text { Elderly } \\
(n=46)\end{array}$ & $\begin{array}{l}\text { Nonelderly } \\
(\mathrm{n}=\mathbf{8 8})\end{array}$ & $\begin{array}{l}\text { Elderly } \\
(n=47)\end{array}$ & $\begin{array}{c}\text { Nonelderly } \\
(\mathrm{n}=\mathbf{8 8})\end{array}$ \\
\hline 0 & 59 & 31 & 17 & 16 & 15 & 7 \\
\hline 1 & 17 & 18 & 21 & 13 & 19 & 14 \\
\hline 2 & 9 & 22 & 17 & 14 & 21 & 14 \\
\hline 3 & 4 & 11 & 17 & 13 & 9 & 14 \\
\hline 4 & 2 & 7 & 4 & 14 & 9 & 11 \\
\hline 5 & 4 & 3 & 9 & 6 & 9 & 9 \\
\hline 6 & 2 & 2 & 4 & 7 & 9 & 6 \\
\hline 7 & 0 & 1 & 9 & 9 & 0 & 4 \\
\hline 8 & 2 & 5 & 2 & 9 & 11 & 22 \\
\hline Mean (SD) & $1.1^{\mathrm{b}}(1.8)$ & $2.0(2.1)$ & $2.7(2.3)$ & $3.4(2.6)$ & $3.0^{\mathrm{b}}(2.5)$ & $4.1(2.7)$ \\
\hline
\end{tabular}

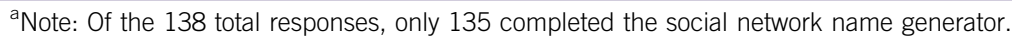

${ }^{\mathrm{b}} \mathrm{P}<0.05$, t-test for difference of means between elderly and nonelderly. 
research on social capital and disaster focuses solely on this type of assistance. My results showed a dramatic difference between network size when resource type was included. Returning to Table 2, financial disaster networks, or the number of individuals able to provide monetary support in a disaster, were much smaller than nonfinancial networks. Specifically, financial networks included, on average, half the number of persons as nonfinancial networks.

The difference between elderly and nonelderly respondents was most pronounced in financial network size. Over half of elderly respondents (59\%) reported zero social ties for financial assistance in a disaster compared to less than onethird of nonelderly persons reporting the same. On average, elderly respondents reported 1.1 persons for financial assistance whereas nonelderly respondents reported 2 persons. This result indicates that many elderly persons assume they will rely on savings or insurance, if they have it, governmental disaster aid, aid from other organizations, or go without financial assistance after a disaster.

Some elderly interviewees had the financial means to care for themselves and their children, whereas others were poor and relied on government assistance. Rick and Nelson were contrasting cases of financial needs. Rick, a 68-year-old retired city worker, owned a new motorhome and a 3-bedroom brick home in Leon County. $\mathrm{He}$ and his wife, daughter, and son-in-law could live in his motorhome following a disaster as he described in his interview:

Fortunately, now if a hurricane were to come I'd probably plywood up the house windows and we'd get in this motorhome and go north....My daughter and son-in-law live in town. They'd probably follow in their car. There's plenty of room in the motorhome [for everyone].

After he described all the features of the motorhome that would allow them to survive for several weeks or months, he explained how he would cover fuel and water costs with savings or his credit card. In contrast, Nelson, an elderly resident of Dixie County, indicated he had no one to rely on for financial assistance if a disaster were to strike. He then described an insurance conundrum that left him financially vulnerable and how he expected to receive government support.

Now I'm living in a trailer that if the wind hit me, the trailer would be probably close to demolished. I can't buy insurance for it. They wanted $\$ 1,800$ a year on a trailer that I bought for $\$ 900$. OK? So I have no insurance. I own the trailer, so I can't buy renters' insurance. I don't know where that leaves me. So I'd just be wiped out. I'd go wherever they [emergency officials] tell me to go....

These quotes highlight the diverse experiences of elderly persons in disaster and how a lack of financial networks will have various consequences depending on individual resources.

To quantify how age affected perceptions of disaster resources while controlling for other factors, I used ordinary least squares regression for overall network size (Table 3, models 1 and 2) and logistic regression for financial social capital (Table 3, models 3 and 4). Beginning with model 1, without controlling for other variables, being elderly resulted in an 1.06 reduction in the overall number of ties $(P=0.047)$. Age alone explained $3.4 \%$ of the variance in overall disaster

\section{TABLE 3}

\begin{tabular}{|c|c|c|c|c|}
\hline \multirow[b]{2}{*}{ Variable } & \multicolumn{2}{|c|}{ Overall Network Size (OLS Regression) } & \multicolumn{2}{|c|}{ Odds of Having a Financial Tie (Logistic Regression) } \\
\hline & Model 1 & Model 2 & Model 3 & Model 4 \\
\hline Elderly & $\begin{array}{c}-1.0^{c} \\
(0.526)\end{array}$ & $\begin{array}{l}-1.13^{c} \\
(0.535)\end{array}$ & $\begin{array}{c}0.25^{d} \\
(0.108)\end{array}$ & $\begin{array}{c}0.28^{d} \\
(0.134)\end{array}$ \\
\hline Leon County & & $\begin{array}{c}-0.51 \\
(0.495)\end{array}$ & - & $\begin{array}{c}3.37^{\circ} \\
(1.599)\end{array}$ \\
\hline Below $150 \%$ poverty line & - & $\begin{array}{l}-0.99^{b} \\
(0.552)\end{array}$ & - & $\begin{array}{c}0.88 \\
(0.449)\end{array}$ \\
\hline Has disability & - & $\begin{array}{c}-1.05 \\
(0.652)\end{array}$ & - & $\begin{array}{c}0.41 \\
(0.232)\end{array}$ \\
\hline Female & - & $\begin{array}{c}0.69 \\
(0.510)\end{array}$ & - & $\begin{array}{c}0.80 \\
(0.383)\end{array}$ \\
\hline Member of organization & & $\begin{array}{c}0.96^{\mathrm{b}} \\
(0.553)\end{array}$ & - & $\begin{array}{c}0.98 \\
(0.479)\end{array}$ \\
\hline Constant & $\begin{array}{c}4.22 \\
(0.298)\end{array}$ & $\begin{array}{c}4.09 \\
(0.638)\end{array}$ & $\begin{array}{c}3.16 \\
(0.831)\end{array}$ & $\begin{array}{c}2.81 \\
(1.660)\end{array}$ \\
\hline $\mathrm{N}$ & 115 & 115 & 115 & 115 \\
\hline$R^{2}$ & 0.034 & 0.159 & 0.073 & 0.162 \\
\hline
\end{tabular}

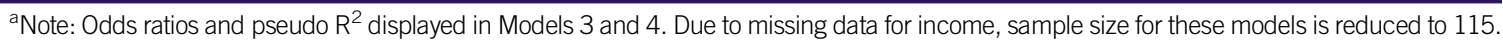
${ }^{\mathrm{b}} P<0.10,{ }^{\mathrm{c}} P<0.05,{ }^{\mathrm{d}} P<0.01$. 
network size. With controls for county, poverty, disability, gender, and being a member of a community organization (such as a church or nonprofit), the effect of age grew slightly stronger $(-1.13)$ and remained statistically significant $(P=0.036)$. Of the variables in model 2 , being elderly had the largest effect on overall network size, followed by living at or below $150 \%$ of the poverty line $(-0.99)$ and being a member of a community organization $(0.96)$. Model 2 predicted $16 \%$ of the variation in overall network size.

Moving to financial disaster networks, because many respondents listed zero individuals who could provide financial assistance, I transformed financial network size into a binary variable and used logistic regression to report the odds ratios of having at least one financial social capital tie. Beginning again with the effect of age alone, elderly individuals were 0.25 times as likely to report having at least one social tie that could provide financial assistance in a disaster. This result was statistically significant $(P=0.001)$. In other words, persons under 65 were 4 times as likely than persons over 65 to report a social tie that could provide financial assistance in a disaster.

Controlling for other variables did not change the effect of age. In model 4 , elderly were 0.28 times as likely as nonelderly to report a financial tie when controlling for other potential explanatory variables. Age was again the strongest explanatory variable, followed by county, with individuals living in Leon County over 3 times as likely to report a financial tie than individuals in Dixie County. Being female, poor, and disabled all reduced the likelihood of reporting at least one financial tie, although none of these variables reached statistical significance. Age alone, in model 3, explained about $7 \%$ of the variance, whereas model 4 had an $\mathrm{R}^{2}$ of 0.16 . These results again supported the hypothesis that the elderly perceive smaller social capital networks for disaster assistance, and this result was most pronounced when considering financial assistance.

\section{DISCUSSION}

This research aimed to address a gap in the literature by comparing social capital resources available in a disaster for elderly and nonelderly persons. My results supported the hypothesis that elderly persons perceived fewer social ties that they could rely on in extreme situations, especially for monetary needs. This finding highlights a compounded vulnerability for elderly persons, which is of most concern for low-income elderly persons or those with health conditions.

This research, like all research, had limitations. This sample was from 2 counties, and as such more research is needed to determine how these results compare to other areas of the United States. Further, the small number of minority respondents precluded me from including this variable in the statistical models. The literature shows that the elderly experience and social capital differ based on race, and future research should assess this variation. ${ }^{16}$ Finally, this research was based on perceptions of social capital. Research following a disaster is needed to determine if these perceptions are accurate. In support of these findings, these respondents are likely drawing from previous experiences to create their expectations (see Table 1), and the average size of support networks found here is consistent with other scholars' postdisaster findings.

With these limitations in mind, what explains the age variation in disaster-specific social capital? This finding is possibly due to shrinking of social networks as people age. Elderly persons are less involved with institutions that support social networking, such as workplaces and schools, ${ }^{43,44}$ which could limit their social resources available in emergencies. My results showed that membership in at least one organization increased the number of ties reported for all persons. Thus, one way to increase disaster-related social capital is to ensure that formal organizations that connect to elderly populations offer disaster information and support and that the leaders of these organizations are aware of the elderly's specific vulnerability. Organizations such as Meals on Wheels or disability support services that reach homebound and low-income elderly provide an opportunity for building social capital. ${ }^{2}$ Mechanisms that help these organizations undertake disaster planning with their clients should be supported.

Another explanation for these results involves the phenomenon of homophily in social networks and perceptions of elderly fragility. In general, people associate with others who are similar to themselves in demographics, such as race, income, and age. ${ }^{45}$ This means we would expect that elderly persons' friends and some family members are also elderly. Being elderly may preclude others from perceiving them as a resource in disaster, particularly nonfinancial resource, due to the physical requirements of placing storm shutters or removing debris, for example. Some interviewees described physical ability as a reason to ask younger and stronger persons for disaster assistance. For example, Henry and Lily, both over 80 years old and living in their own home, recalled a recent routine emergency in which they needed help. Notice how Lily commented on the age of each person as a reason for identifying them as sources of assistance.

When our water pipes froze, people from the church came to see what they could do to help, and we have a friend that lives in the next town. And of course they're all younger than what we are. At the time our son was not up here, so they came and did what they could to help us....I think our son would probably be the first person I'd call [now]. If I thought that our damage maybe was worse than [near the church], I might call my pastor. He's a young man too... [while] most of our church is elderly like us.

But physical ability should not affect perceptions about financial assistance. Thus, this reason does not explain why 
being elderly had such a large effect on financial assistance. Further research is needed to determine why the elderly are much less likely to view social ties as potential sources of financial assistance in a disaster. With increasing numbers of Americans reaching 65 each day, these results point to the importance of understanding the relationship of age and social capital to disaster vulnerability and resilience.

\section{About the Authors}

Department of Sociology, Louisiana State University, Baton Rouge, Louisiana.

Correspondence and reprint requests to Michelle Annette Meyer, $\mathrm{PhD}$, Department of Sociology, Louisiana State University, Baton Rouge, LA 70803 (e-mail: mmeyer@ lsu.edu).

\section{Acknowledgments}

Funding for the research was provided through a National Periship Dissertation Fellowship sponsored by the Public Entity Risk Institute, the National Science Foundation, the Natural Hazards Research and Applications Information Center, and Swiss Re. Special thanks to Lori Peek and Ann-Margaret Esnard for comments on drafts of this work and two anonymous reviewers for their feedback.

Published online: November 14, 2016.

\section{REFERENCES}

1. Ngo EB. When disasters and age collide: reviewing vulnerability of the elderly. Nat Hazards Rev. 2001;2(2):80-89. http://dx.doi.org/10.1061/ (ASCE)1527-6988(2001)2:2(80).

2. Fernandez LS, Byard D, Lin C, et al. Frail elderly as disaster victims: emergency management strategies. Prehosp Disaster Med. 2002;17(02): 67-74. http://dx.doi.org/10.1017/S1049023X00000200.

3. Wisner B, Blaikie P, Cannon T, et al. The challenge of disasters and our approach. In Wisner B, Blaikie P, Cannon T, et al, eds. At Risk: Natural Hazards, People's Vulnerability and Disasters. London: Routledge; 2004:3-48.

4. Peek L. Age. In: Phillips BD, Thomas DSK, Fothergill A, et al, eds. Social Vulnerability to Disasters. Boca Raton, FL: CRC Press; 2010:155-185.

5. Bolin R, Klenow DJ. Response of the elderly to disaster - an age-stratified analysis. Int J Aging Hum Dev. 1983;16(4):283-296. http://dx.doi.org/ 10.2190/MQEG-YN39-8D5V-WKMP.

6. Perry RW, Lindell MK. Aged citizens in the warning phase of disasters: re-examining the evidence. Int J Aging Hum Dev. 1997;44(4):257-267. http://dx.doi.org/10.2190/RT3X-6MEJ-24AQ-03PT.

7. Fothergill A, Peek L. Poverty and disasters in the United States: a review of recent sociological findings. Nat Hazards. 2004;32(1):89-110. http:// dx.doi.org/10.1023/B:NHAZ.0000026792.76181.d9.

8. Administration on Aging (AoA). Profile of Older Americans: 2012. Administration for Community Living website. http://www.aoa.acl.gov/ Aging_Statistics/Profile/2012/index.aspx. Accessed October 13, 2016.

9. Durant TJ. The utility of vulnerability and social capital theories in studying the impact of Hurricane Katrina on the elderly. J Fam Issues. 2011;32(10):1285-1302. http://dx.doi.org/10.1177/0192513X11412491.

10. Clive A, Davis EA, Hansen R, et al. Disability. In: Thomas DSK, Fothergill A, Phillips BD, eds. Social Vulnerability to Disaster. Boca Raton, FL: CRC Press; 2010:187-216.

11. Wolf J, Adger WN, Lorenzoni I, et al. Social capital, individual responses to heat waves and climate change adaptation: an empirical study of two UK cities. Glob Environ Change. 2010;20(1):44-52. http://dx.doi.org/ 10.1016/j.gloenvcha.2009.09.004.

12. Bourdieu P. The forms of capital. In: Richardson JG, ed. Handbook of Theory and Research for the Sociology of Education. New York: Greenwood; 1985:241-258.
13. Adger WN, Hughes TP, Folke C, et al. Social-ecological resilience to coastal disasters. Science. 2005;309(5737):1036-1039. http://dx.doi.org/ 10.1126/science.1112122.

14. Quarantelli EL. A social science research agenda for the disasters of the 21st century: theoretical, methodological and empirical issues and their professional implementation. In: Perry RW, Quarantelli EL, eds. What Is a Disaster: New Answers to Old Questions. Philadelphia: XLibris Corp; 2005:325-396.

15. Aguirre BE, Wenger DE, Glass TA, et al. The social organization of search and rescue: evidence from the guadalajara gasoline explosion. Int $J$ Mass Emerg Disasters. 1995;13:67-92.

16. Elliott JR, Haney TJ, Sams-Abiodun P. Limits to social capital: comparing network assistance in two New Orleans neighborhoods devastated by Hurricane Katrina. Sociol Q. 2010;51(4):624-648. http:// dx.doi.org/10.1111/j.1533-8525.2010.01186.x.

17. Tobin-Gurley J, Peek L, Loomis J. Displaced single mothers in the aftermath of Hurricane Katrina: resource needs and resource acquisition. Int J Mass Emerg Disasters. 2010;28:170-206.

18. Kaniasty K, Norris FH. In search of altruistic community: patterns of social support mobilization following Hurricane Hugo. Am J Community Psychol. 1995;23(4):447-477. http://dx.doi.org/10.1007/BF02506964.

19. Hurlbert JS, Haines VA, Beggs JJ. Core networks and tie activation: what kinds of routine networks allocate resources in nonroutine situations? Am Sociol Rev. 2000;65(4):598-618. http://dx.doi.org/ $10.2307 / 2657385$.

20. Hawkins RL, Maurer K. Bonding, bridging and linking: how social capital operated in New Orleans following Hurricane Katrina. Br J Soc Work. 2010;40(6):1777-1793. http://dx.doi.org/10.1093/bjsw/ bcp087.

21. Wrzus C, Hänel M, Wagner J, et al. Social network changes and life events across the life span: a meta-analysis. Psychol Bull. 2013;139(1): 53-80. http://dx.doi.org/10.1037/a0028601.

22. McPherson M, Smith-Lovin L, Brashears ME. Social isolation in America: changes in core discussion networks over two decades. Am Sociol Rev. 2006;71(3):353-375. http://dx.doi.org/10.1177/000312240607100301.

23. Zhao Y. Social networks and reduction of risk in disasters: an example of the Wenchuan earthquake. In: Yeung WJ, Yap MT, eds. Economic Stress, Human Capital, and Families in Asia. New York City: Springer; 2013:171-182. http://dx.doi.org/10.1007/978-94-007-7386-8_10.

24. Peacock WG, Morrow BH, Gladwin H. Hurricane Andrew: Ethnicity, Gender and the Sociology of Disaster. New York: Routledge; 1997.

25. Geller AM. The susceptibility of older adults to environmental hazards. Generations. 2009;33:10-18.

26. Kilijanek TS, Drabek TE. Assessing long-term impacts of a natural disaster: a focus on the elderly. Gerontologist. 1979;19(6):555-566. http:// dx.doi.org/10.1093/geront/19.6.555.

27. Klinenberg E. Heat Wave: A Social Autopsy of Disaster in Chicago. Chicago: University of Chicago Press; 2002. http://dx.doi.org/10.7208/ chicago/9780226026718.001.0001.

28. Procidano ME, Heller K. Measures of perceived social support from friends and from family: three validation studies. Am J Community Psychol. 1983;11(1):1-24. http://dx.doi.org/10.1007/BF00898416.

29. Lowe SR, Chan CS, Rhodes JE. Pre-hurricane perceived social support protects against psychological distress: a longitudinal analysis of lowincome mothers. J Consult Clin Psychol. 2010;78(4):551-560. http://dx. doi.org/10.1037/a0018317.

30. Lin N. Building a network theory of social capital. Connections. 1999;22:28-51.

31. Portes A. The two meanings of social capital. Sociol Forum. 2000; 15(1):1-12. http://dx.doi.org/10.1023/A:1007537902813.

32. Chamlee-Wright E, Storr VH. Social capital as collective narratives and post-disaster community recovery. Sociol Rev. 2011;59(2):266-282. http://dx.doi.org/10.1111/j.1467-954X.2011.02008.x.

33. Aldrich DP. The power of people: social capital's role in recovery from the 1995 Kobe Earthquake. Nat Hazards. 2011;56(3):595-611. http://dx. doi.org/10.1007/s11069-010-9577-7. 
34. Aldrich DP, Meyer MA. Social capital and community resilience. Am Behav Sci. 2015;59(2):254-269. http://dx.doi.org/10.1177/0002764214550299.

35. Dillman DA. Mail and Internet Surveys: The Tailored Design Method. New York: Wiley; 2007.

36. Tourangeau R. Survey research and societal change. Annu Rev Psychol. 2004;55(1):775-801. http://dx.doi.org/10.1146/annurev.psych.55.090902. 142040.

37. Kaplowitz MD, Hadlock TD, Levine R. A comparison of web and mail survey response rates. Public Opin Q. 2004;68(1):94-101. http://dx.doi. org $/ 10.1093 / \mathrm{poq} / \mathrm{nfh} 006$.

38. Knoke D, Yang S. Social Network Analysis. 2nd ed. Thousand Oaks, CA: Sage; 2008. http://dx.doi.org/10.4135/9781412985864.

39. Schensul JJ, LeCompte MD, Cromley EK, et al. Mapping Social Networks, Spatial Data, and Hidden Populations. Walnut Creek, CA: AltaMira Press; 1999.
40. Saldaña J. The Coding Manual for Qualitative Researchers. Los Angeles: Sage; 2009.

41. Charmaz K. Grounded theory. In: Emerson RM, ed. Contemporary Field Research: Perspectives and Formulations. Prospect Heights, IL: Waveland Press; 2001:335-352.

42. Strauss A, Corbin J. Basics of Qualitative Research: Techniques and Procedures for Developing Grounded Theory. Thousand Oaks, CA: Sage Publications; 1990.

43. Gray A. The social capital of older people. Ageing Soc. 2009;29(01):5-31. http://dx.doi.org/10.1017/S0144686X08007617.

44. Cornwell B, Laumann EO, Schumm LP. The social connectedness of older adults: a national profile. Am Sociol Rev. 2008;73(2):185-203. http://dx.doi.org/10.1177/000312240807300201.

45. McPherson M, Smith-Lovin L, Cook JM. Birds of a feather: homophily in social networks. Annu Rev Sociol. 2001;27(1):415-444. http://dx.doi. org/10.1146/annurev.soc.27.1.415. 